\title{
SUPERVISI PENDIDIKAN \\ DALAM PENINGKATAN MUTU PENDIDIKAN DI SEKOLAH
}

\author{
Oleh \\ I Made Ariasa Giri \\ Fakultas pada Dharma Acarya IHDN Denpasar
}

\begin{abstract}
Supervision is imperative for the improvement of the school education quality. In doing a supervision the supervisor should pay attention to the process, effectiveness, the system, the information, the evaluation, the principles, the programs, and the objectives, and the clinical model.
\end{abstract}

Key words: supervision, education, quality, school

\section{PENDAHULUAN}

Supervisi/pengawasan dalam lembaga pendidikan berkembang dan mengalami perubahan sesuai dengan tuntutan perkembangan zaman. Bila masalalu pengertian supervisi lebih ditekankan pada pemberianpemberian yang berorientasi pada benar salah sebuah pekerjaan dengan cara yang tidak jarang, menakutkan memberikan sanksi dan menjerumuskan, maka pada saat ini supervisi lebih ditekankan pada kegiatan pembinaan dan pengembangan pada orang yang disupervisi. Hal ini senada dengan apa yang dikemukakan oleh Neagley (1980:20), bahwa supervisi merupakan layanan kepada guru-guru yang bertujuan menghasilkan perbaikan intruksional, belajar dan kurikulum.

Pengertian tersebut mengisyaratkan bahwa dalam proses supervisi perlu ada suasana kondusif, hubungan yang interaktif dalam suasana kolegial sebagaimana diungkapkan Acheson and Gall yang mengemukakan prinsipprinsip yang perlu dikembangkan dalam supervisi yaitu (1) interaktif, artinya Supervisor dan Supervise pada hakekatnya sederajat mitra dan saling membantu dalam meningkatkan profesionalnya, (2) demokratif, maksudnya bersikap terbuka dalam mengemukakan dan menghargai pendapat lain, (3) supervisee oriented bukan supervisor oriented

Pendapat senada dikemukakan dalam Buku Petunjuk Pelaksanaan Supervisi Pendidikan di Sekolah Kurikulum 1994 (SLTP dan SMA) bahwa Supervisi ialah bantuan yang diberikan kepada seluruh staf sekolah untuk mengembangkan situasi belajar mengajar yang lebih baik. Itu berarti bahwa kegiatan supervisi apapun yang hendak dilakukan Kepala Sekolah kegiatan tersebut harus dirasakan sebagai bantuan bagi yang di supervisi. Sebagai contoh bila yang di supervisi itu guru mata pelajaran, maka tugas-tugas yang berkaitan dengan tugas gurulah yang perlu diperhatikan, umpama (1) menyusun AMP, pembuatan program tahunan, semester, silabus, RPP, (2) pelaksanaan KBM, (3) Penyusunan evaluasi, analisis butir soal dan daya serap. Jika yang hendak disupervisi itu pegawai administrasi, kemungkinan bantuan yang perlu diberikan yang berhubungan dengan (a) pengisian buku induk dan Klapper, (b) administrasi perpustakaan, keuangan dan lain sebagainya

Menurut Murdick pengawasan merupakan proses dasar yang secara esensial tetap 
diperlukan bagaimanapun rumit dan luasnya suatu organisasi. Proses dasarnya terdiri dari tiga tahap (1) menetapkan standar pelaksanaan, (2) pengukuran pelaksanaan pekerjaan dibandingkan dengan standar, dan (3) menentukan kesenjangan (deviasi) antara pelaksanaan dengan standar dan rencana.

\section{PEMBAHASAN}

\subsection{Proses Pengawasan/Supervisi}

Proses pengawasan/supervisi meliputi dua hal, yaitu menetapkan standar-standar pelaksanaan pekerjaan dan pengukuran hasil/ pelaksanaan pekerjaan. Kedua hal tersebut dapat diuraikan sebagai berikut.

a. Menetapkan standar-standar pelaksanaan pekerjaan

Penentuan standar mencakup kriteria untuk semua lapisan pekerjaan (job performance) yang terdapat dalam suatu organisasi. Standar ialah kriteria-kriteria untuk mengukur pelaksanaan pekerjaan. Kriteria tersebut dapat dalam bentuk kuantitatif ataupun kuanlitatif. Standar pelaksanaan (standard performance) ialah suatu pernyataan mengenai kondisi-kondisi yang terjadi bila suatu pekerjaan dikerjakan secara memuaskan.

Umumnya standar pelaksanaan pekerjaan bagi suatu aktivitas menyangkut kriteria: ongkos, waktu, kuantitas, dan kualitas. Dengan mengadaptasikan karya Koonts dan O. Donnel, Murdick mengemukakan lima ukuran kritis sebagai standar: 1) fisik, 2) ongkos, 3) program, 4) pendapatan, dan 5) standar yang tak dapat diraba (intangible).

Diantara standar-standar yang telah dikemukakan, standar intangible merupakan standar yang sulit diukur, biasanya tidak dinyatakan dalam ukuran kuantitas. b. Pengukuran Hasil/Pelaksanaan Pekerjaan Tahap kedua dari proses pengawasan adalah pengukuran hasil/pelaksanaan. Metode dan teknik koreksinya dapat dilihat/dijelaskan klasifikasi fungsi-fungsi manajemen: (1) perencanaan: garis umpan balik proses manajemen dapat berwujud meninjau kembali rencana mengubah tujuan atau mengubah standar, (2) pengorganisasian: memeriksa apakah struktur organisasi yang ada itu cukup sesuai dengan standar, apakah tugas dan kewajiban telah dimengerti dengan baik, dan apakah diperlukan penataan kembali orangorang, (3) penataan staf: memperbaiki sistem seleksi, memperbaiki sistem latihan, dan menata kembali tugas-tugas, (4) pengarahan: mengembangkan kepemimpinan yang lebih baik, meningkatkan motivasi, menjelaskan pekerjaan yang sukses, penyadaran akan tujuan yang secara keseluruhan apakah kerja sama antara pimpinan dan anak buah berada dalam standar. Untuk lebih jelasnya, dapat dilukiskan dengan bagan tentang hubungan langkahlangkah proses pengawasan tersebut.

\subsection{Pengawasan dan Konsep Sistem}

Dalam pengawasan dan konsep sistem dibahas dua hal pokok, yaitu pegawasan menurut Paham Klasik dan Pengawasan dan Konsep Sistem Cybernetic, sebagai berikut.

\section{a. Pengawasan Menurut Paham Klasik \\ Menurut paham klasik, pengawasan merupakan coercion atau compeling artinya proses yang bersifat memaksa-maksa agar kegiatan-kegiatan pelaksanaan dapat disesuaikan dengan rencana yang telah ditetapkan.}


Bagan 11 : Langkah-langkah Dasar proses Pengawasan

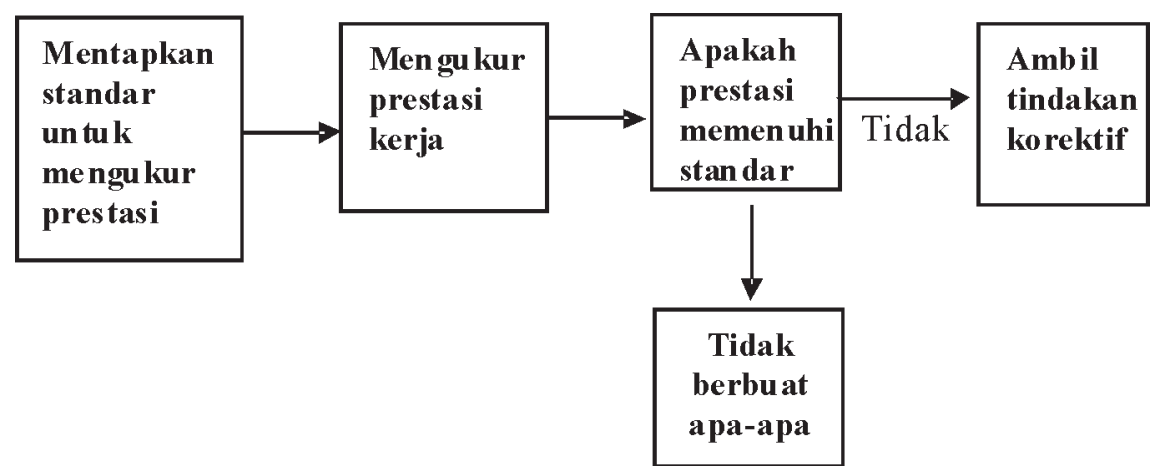

\section{b. Pengawasan dan Konsep Sistem Cybernetic}

Berlainan dengan paham klasik, pengawasan menurut konsep sistem didasarkan kepada kesadaran yang bersifat cybernetic atau sistem cybernatic, yaitu sistem kesadaran yang memandang organisasi atau ekosistem sebagai mesim homeostatic yang bekerja secara otomatis. Faham pengawasan sebagai suatu sistem cybernetic adalah seperti thermostat merupakan sebuah sistem yang mengatur diri sendiri. Prinsip dasar yang menjadi kunci dalam sistem pengawasan adalah umpan balik (feedback).

Karakteristik pokok sistem cybernetic: (1) menentukan keseimbangan (equilibrium); (2) menerima perubahan-perubahan di dalam lingkungan sebagai umpan balik terhadap sistem; (3) memindahkan informasi lingkungan eksternal ke dalam sistem; dan (4) melakukan tindakan korektif yang cepat tatkala output beroksilasi di luar batas kesadaran.

Konsep pengawasan yang diterapkan ke dalam suatu sistem dilukiskan dalam bagan. Bagan ini menjelaskan bagaimana fungsi pokok sistem mengadakan introspeksi yang didasarkan pada informasi umpan balik dari lingkungan eksternal.

\subsection{Informasi dan Pengawasan}

Informasi dan pengawasan dalam hal ini meliputi (1) pengawasan sebagai suatu sistem informasi,(2) jenis-jenis informasi pengawasan,
(3) pendekatan sistem dalam pengawasan (feed forward), sebagai berikut.

1) Pengawasan sebagi Suatu Sistem Informasi Sesuai dengan pengertian pengawasan itu adalah menetapkan standar pelaksanaan pekerjaan, pengukuran pelaksanaan dibandingkan dengan standar dan mengoreksi kesenjangan-kesenjangan maka proses pengawasan tidak akan terlaksana tanpa informasi. Oleh karena itu, sistem pengawasan harus dipandang sebagai suatu sistem informasi, karena kecepatan dan ketepatan tindakan korektif sebagai hasil akhir proses pengawasan bergantung pada macamnya informasi yang diterima.

\section{2) Jenis-Jenis Informasi Pengawasan}

Karakteristik informasi untuk pelaksanaan pengawasan berbeda dengan informasi yang diperlukan untuk perencanaan. Perencanaan terkanannya pada struktur masa depan, sedangkan pengawasan tekanannya pada hal yang baru saja terjadi dan kecenderungankecenderungan yang khusus.

Umumnya informasi pengawasan dapat diklasifikasikan sebagai berikut: (1) pemasaran pemakaian jasa/barang yaitu informasi yang berhubungan dengan kemajuan rencana kebutuhan antara lain menyangkut quota daerah pemasaran tenaga. Informasi pemasaran pada dasarnya adalah untuk mengukur rencana pemasokan dengan pelaksanaan; (2) pabrik 
yaitu informasi yang dipakai untuk mengukur pelaksanaan terhadap rencana keuangan organisasi. Katagorinya menyangkut tenaga, bahan-bahan dan investoris dan persediaan barang; (3) personal yaitu informasi yang berhubungan dengan tindakan pelaksanaan kerja personal; (4) keuangan yaitu informasi yang berhubungan dengan pelaksanaan rencana keuangan, perputaran uang kas; (5) riset, pengembangan, dan permesinan yaitu informasi yang menyangkut hasil penelitian pengembangan dan teknik pemersinan.

3) Pendekatan Sistem dalam Pengawasan (Feed Forward)

Pengawasan berdasarkan pendekatan tradisional mempunyai beberapa kelemahan/ keuangan, antara lain: (1) standar pelaksanaan, umumnya dikaitkan dengan rencana keuangan jangka pendek sehingga mengabaikan kaitannya dengan pencapaian tujuan keseluruhan (overall); (2) proses pengawasan, menimbulkan konotasi tekanan, inspeksi dan mencari-cari kesalahan; (3) laporan pengawasan dipandang sebagai alat ukur kemajuan bagian-bagian dan bukan untuk memperoleh pelaksanaan; (4) keterlambatan merupakan ciri sehingga jarak waktu antara terjadinya penyimpangan sampai ditemukannya tindakan korektif, suka terlambat.

Pengawasan modern berdasarkan pendekatan sistem dibangun berdasarkan empat ide pokok; (1) integrasi perencanaan dan pengawasan; (2) mengaitkan sistem pengawasan dengan struktur organisasi; organisasi tidak akan mencapai sinergistik apabila bagian-bagian tidak saling mengaitkan dalam pencapaian keseluruhan tujuan; (3) sistem desain untuk pengambilan keputusan, dan bukan bersifat laporan post facto; (4) informasi yang tepat pada waktunya adalah esensial.

Syarat dasar setiap sistem pengawasan adalah feedback. Sistem pengawasan yang berdasarkan pada prinsip feedback, bersifat setelah terjadi kesenjangan. Prinsip ini didasarkan pada data dan sistem informasi yang pada hakikatnya bersifat historis.

Sistem pengawasan modern menggunakan prinsip lain yang disebut pengawasan feedforward. Cara kerjanya adalah mengantisipasi kesenjangan di dalam sistem umpan balik dengan cara memonitor masukanmasukan dan memprediksi efek masukan ini terhadap variabel-variabel hasil atau output. Dengan cara demikian tindakan koreksi pengubahan masukan dapat dilakukan sebelum terjadi kesenjangan. Prinsip ini akan membawa sistem output ke dalam titik keseimbangan atau equilbrium terhadap hasil-hasil yang diharapkan sebelum dilakukan pengukuran terhadap hasil berdasarkan prinsip feedback.

Proses pengawasan feedforward pada dasarnya merupakan suatu proses analisis yang sangat hati-hati terhadap variabel-variabel masukan yang dikaitkan dengan output yang diharapkan. Input dimonitor dan diubah dalam rangka pencapaian hasil yang diinginkan sebelum terjadi kesenjangan.

\subsection{Pengawasan yang Efektif}

Pengawasan yang efektif didasarkan pada sisteminformasi manajemen (MIS) yang efektif. MIS dapat ditetapkan sebagai metode formal untuk memberikan informasi yang dibutuhkan oleh manajer agar dapat melaksanakan tugas secara efektif. Nilai informasi yang diberikan oleh MIS bergantung pada kualitas, kuantitas, dapat diperoleh setiap saat, dan relevan dengan kegiatan manajemen. Informasi yang dibutuhkan oleh manajer berbeda-beda bergantung pada tingkat hierarki mereka. Misalnya, manajer puncak membutuhkan informasi perencanaan strategik, manajer menengah membutuhkan sumber-sumber informasi baik yang berasal dari luar maupun dari dalam, manajer tingkat bawah yang berurusan dengan pengendalian operasi sering memerlukan informasi yang akurat dan yang sangat rinci, dan sebagian besar bersumber dari dalam. 
Pengawasan yang efektif harus melibatkan semua tingkat manajer dari tingkat atas sampai tingkat bawah, dan kelompok-kelompok kerja. Konsep pengawasan efektif ini mengacu pada pengawasan mutu terpadu atau total Quality Control (TQS).Figenbaum (1991) menyatakan bahwa Total Quality Control is an effective system for integrating the quality development, quality maintenance and quality improvement efforts of the varions groups in an organization so as to enable marketing, engeneting, pruduction, and service at the most economical levels which allow for full customer satisfaction. TQC sebagai suatu sistem untuk memadukan bermacam-macam kualitas (pemeliharaan, perbaikan, pengembangan) produksi, dan pemasarannya dengan tingkat harga yang paling ekonomis tetapi dapat memberikan kepuasan bagi para pemakainya.

Di dalam dunia pendidikan QTC akan dapat efektif, jika pada setiap tingkatan pendidikan mempunyai keterpaduan, kerja sama yang baik antara kelompok kerja (guru) dan pimpinan dalam melakukan pengawasan mutu. Partisipasi penuh setiap tingkatan atau kelompok dalam melakukan pengawasan mutu biasanya disebut dengan Gugus Kendali Mutu (GKM) yang bertujuan menjamin keberhasilan pengendalian mutu terpadu. Prinsip yang dipergunakan adalah kontribusi setiap anggota dan ide diterima dipertimbangkan yang relevan dengan program dan nilai-nilai yang dimiliki. Dalam hal ini tidak dikenal hubungan atasan dan bawahan, tetapi kita yang komitmennya sama demi perbaikan mutu.

Beberapa kondisi yang harus diperhatikan jika pengawasan ini dapat berfungsi efektif, antara lain:

1) Pengawasan harus dikaitkan dengan tujuan, dan kriteria yang dipergunakan dalam sistem pendidikan, yaitu relevansi, efektivitas, efisiensi, dan produktivitas. Tujuan-tujuan pendidikan dalam berbagai tingkatan, mulai Tujuan Pendidikan
Nasional, Tujuan Institusional, Tujuan Kurikuler, Tujuan-tujuan mata pelajaran (TIU, TIK). Agar standar pengawasan pendidikan ini berfungsi efektif semua itu harus dipahami dan diterima oleh setiap anggota organisasi sebagai bagian integral, misalnya sistem UANAS sebagai standar kendali mutu pendidikan harus dianggap normal dan perlu.

2) Sulit, tetapi standar yang masih dapat dicapai harus ditentukan. Ada dua tujuan pokok, yaitu: (1) untuk memotivasi, dan (2) untuk dijadikan patokan guna membandingkan dengan prestasi. Artinya jika pengawasan ini efektif akan dapat memotivasi seluruh anggota untuk mencapai prestasi yang tinggi. Karena tantangan biasanya menimbulkan berbagai reaksi, maka daya upaya untuk mencapai standar yang sulit mungkin dapat membangkitkan semangat yang lebih besar untuk mencapainya daripada kalau yang harus dipernuhi itu hanya standar yang mudah. Namun demikian, jika target terlampau tinggi atau terlalu sulit kemungkinan juga akan menimbulkan patah semangat. Oleh karena itu, tidak menetapkan standar yang terlampau sulit sehingga bukan meningkatkan prestasi belajar/pendidikan, malah menurunkan prestasi.

3) Pengawasan hendaknya disesuaikan dengan sifat dan kebutuhan organisasi. Di sini perlu diperhatikan pola dan tata organisasi, seperti susunan, peraturan, kewenangan dan tugas-tugas yang telah digariskan dalam uraian tugas (job description).

4) Banyaknya pengawasan harus dibatasi. Artinya jika pengawasan terhadap karyawan terlampau sering ada kecenderungan mereka kehilangan otonominya dan dapat dipersepsi pengawasan itu sebagai pengekangan. Di beberapa segi dianggap bahwa pengawasan itu 
sedemikian ketatnya, sehingga karyawan cenderung mulai berpikir untuk melakukan pembelaan diri daripada berusaha menunjukkan prestasi kerja yang baik.

5) Sistem pengawasan harus dikemudi (steering controls) tanpa mengorbankan otonomi dan kehormatan manajerial tetapi fleksibel, artinya sistem pengawasan menunjukkan kapan, dan di mana tindakan korektif harus diambil. Masalahnya pengawasan mempunyai implikasi emosional dan motivasional yang berhubungan dengan konsekuensi fungsional dan disfungsional.

6) Pengawasan hendaknya mengacu pada tindakan perbaikan, artinya tidak hanya mengungkap penyimpangan dari standar, tetapi penyediaan alternatif perbaikan menentukan tindakan perbaikan.

7) Pengawasan hendaknya mengacu pada prosedur pemecahan masalah, yaitu: menemukan masalah, menemukan penyebab, membuat rancangan penanggulangan, melakukan perbaikan, mengeek hasil perbaikan, mencegah timbulnya masalah yang serupa.

\subsection{Evaluasi Program}

Evaluasi adalah pembuatan pertimbangan menurut suatu perangkat kriteria yang disepakati dan dapat dipertanggungjawabkan. Menurut TR Morrison (Abdjul, 1982) ada tiga faktor penting dalam konsep evaluasi, yaitu pertimbangan (judgement) deskripsi obyek penilaian, dan kriteria yang bertanggung jawab (defensible criteria). Aspek keputusan itu yang membedakan evaluasi sebagai suatu kegiatan dan konsep dari kegiatan dan konsep lainnya, seperti pengukuran (measurement). Dalam hubungannya dengan manajemen pendidikan, tujuan evaluasi antara lain:

1) Untuk memperoleh dasar bagi pertimbangan akhir suatu periode kerja, apa yang telah dicapai, apa yang belum dicapai, dan apa yang perlu mendapat perhatian khusus.
2) Untuk menjamin cara kerja yang efektif dan efisien yang membawa organisasi kepada penggunaan sumber daya pendidikan (manusia/tenaga, sarana/prasarana, biaya) secaras efisien ekonomis.

3) Untuk memperoleh fakta tentang kesulitan, hambatan, penyimpangan dilihat dari aspek tertentu misalnya program tahunan, kemajuan belajar.

Pengkajian tentang evaluasi di sini lebih terfokus pada evaluasi prosgram karena dikaitkan dengan kepentingan pimpinan/ manajer. Sebagaimana bidang-bidang lainnya evaluasi program menggunakan konsep-konsep penting dan khusus sebagai alat analisis. Konsep-konsep itu meliputi:

a) Populasi sasaran (target population), yaitu kelompok yang dituju sebagai suatu sasaasn.

b) Evaluasi komprehensif (comprehensive evaluation), yaitu evaluasi yang mencakup monitoring, menilai dampak dan analisis manfaat biaya (cost benefit).

c) Cost benefit analysis adalah studi hubungan antara ongkos/biaya dan hasil/ manfaat dario program yang dinyatakan dalam bentuk uang (analisis keuntungan).

d) Analisis keefektivan biaya (cost effectivenes analysis) yaitu studi tentang hubungan antara ongkos dan hasil program yang dinyatakan dengan biaya per unit hasil yang dicapai.

e) Sistem penyampaian (delivery system): yaitu pengaturan organisasi mencakup staf, prosedur, dan kegiatan, sarana fisik dan bahan-bahan yang diperlukan untuk menjalankan program.

f) Perencanaan, yaitu proses menjabarkan tujuan-tujuan umum ke dalam tujuan-tujuan khusus bagi populasi sasaran yang relevan.

g) Unsur-unsur program, yaitu aspek-aspek yang jelas dan diskrit dari suatu program.

h) Efek-efek yang mengacaukan (confouding), yaitu hasil yang mengaburkan 
efek yang sesungguhnya dari suatu program.

i) Hasil netto, yaitu dampak suatu program sesudah dikeluarkan efek pengacau.

j) Efek stokastik (Stochastic effects), yaitu fluktuasi pengukuran yang disebabkan faktor kebetulan (chance).

Bagaimana kerangka dasar evaluasi program. Secara sederhana dapat dibagankan sebagai berikut.

\section{1) Unsur-unsur Program}

Pada umumnya, unsur program dapat ditentukan dengan dua cara pendekatan, yaitu pendekatan struktural dan fungsional. Unsurunsur program suatu pendekatan struktural meliputi (a) tujuan program, (b)seleksi dasar kegiatan belajar, (c) rasional dan pendekatan terhadap evaluasi, (d) karakteristik siswa (kemampuan). Terkait unsur-unsur program pendek atau fungsional, ada beberapa hal yang perlu diperhatikan, meliputi (a) iklim kelas, (b) sistem penunjang administrasi, (c) karakteristik guru, (d) gaya implementasi.
Sedangkan pendekatan fungsional dapat dipertimbangkan dalam menilai keseluruhan program suatu sekolah. Berbeda dengan pendekatan struktural yang mementingkan komponen utama, tetapi pendekatan fungsional menekankan pada fungsi-fungsi utama dari suatu program, misalnya (a) evaluasi dan seleksi, (b) diagnosis dan remedial, (c) penjadwalan, (d) kompetensi fisik, (f) fungsi kepustakaan/sumber bacaan, (g) penempatan kerja, (h) latihan jabatan, (i) testing.

\section{2) Pengumpulan Data Unsur Program}

Kegiatan yang diperlukan adalah mengumpulkan data tentang program dan mengorganisasi bahan secara sistematik. Deskripsi program dibedakan dua tingkat yaitu, persepsi dan realitas. Persepsi merupakan apa yang dipandang oleh orang-orang yang dikenai program merupakan hakikat program. Realita adalah berdasarkan observasi terhadap program, apakah yang dipandang evaluator merupakan tujuan aktual program. Teknik pengumpulan data untuk persepsi dan operasional/realita untuk setiap unsur program dapat dibedakan sebagai berikut.

Contoh : Teknik Koleksi Data

\begin{tabular}{|l|l|l|}
\hline \multicolumn{1}{|c|}{ Unusr Program } & \multicolumn{1}{c|}{ Persepsi } & \multicolumn{1}{c|}{ Operasional } \\
\hline Observasi & Kuesioner & Observasi langsung \\
Kegiatan belajar & Interviu & Analisis hasil \\
Seleksi isi & Analisis dokumen & Interviu \\
Evaluasi & & Analisis interaksi \\
Iklim & & Etnografi \\
Karakteristik siswa & & Simulasi \\
Penunjang administrasi & & Catatan harian \\
Gaya interpretasi & & Teknik kritikal insiden \\
\hline
\end{tabular}


2.6. Prinsip-Prinsip Supervisi/Pengawasan

Hal-hal yang perlu diperhatikan dalam melaksanakan supervisi antara lain sebagai berikut.

1. Suasana kemitraan tidak menimbulkan rasa takut tetapi rasa saling memerlukan, hubungan kolegial dan bersifat interaktif

2. Supervisi harus bersifat praktis, dalam arti dapat dikerjakan (workable), sesuai situasi dan kondisi sekolah

3. Sistematis artinya supervisi dikembangkan dengan perencanaan yang matang sesuai dengan sasaran yang diinginkan

4. Obyektif artinya memberikan masukan sesuai dengan aspek yang terdapat dalam instrumen

5. Realistis maksudnya didasarkan atas kenyataan yang sebenarnya yaitu pada keadaan atau hal-hal yang sudah dipahami dan dilakukan oleh para staf sekolah

6. Supervisi bersifat bantuan, bukannya instruksi dengan tujuan peningkatan kemampuan mengajar dan pembentukan sikap profesional

7. Kreatif artinya supervisi mengembangkan inisiatif dan kreatif guru dalam proses belajar mengajar

8. Antisipatif maksudnya diarahkan untuk menghadapi kesulitan yang mungkin terjadi

9. Konstruktif artinya memberikan saransaran perbaikan kepada yang di supervisi untuk terus berkembang sesuai ketentuan atau aturan yang berlaku

10. Kooperatif artinya supervisi mengembangkan perasaan kebersamaan untuk menciptakan dan mengembangkan situasi belajar mengajar

\subsection{Sasaran Supervisi/Pengawasan}

Sasaran supervisi dapat mengenai kegiatan atau aspek yang disupervisi maupun orang yang melakukannya. Sebagai contoh :

Yang hendak di supervisi kegiatan pengisian buku induk, apakah pengisiannya lengkap, teratur dan sebagainya. Kegiatan ini merupakan salah satu dari aspek supervisi. Namun buku induk tersebut adalah garapan Kepala T.U. Dalam hal ini Kepala T.U adalah orang yang melakukannya. Melalui supervisi akan dapat disimpulkan tentang kemampuannya, keterampilannya menulis dan sebagainya.

1. Aspek yang disupervisi :

a. Administrasi, yang mencakup antara lain administrasi sekolah secara umum, kesiswaan, ketenagaan, perlengkapan pendidikan, keuangan dan hubungan sekolah dengan masyarakat

b. Edukatif, yang mencakup kurikulum, $\mathrm{KBM}$, pelaksanaan bimbingan dan Konseling (BP)

2. Orang yang disupervisi (supervisee)

a. Guru mata pelajaran

b. Guru pembimbing

c. Tenaga edukatif lainnya

d. Tenaga administrasi

e. Siswa

Yang melakukan supervisi (supervisor) adalah Kepala Sekolah dan Pengawas, serta personal yang sedang ditugasi.

Supervisi Klinis (Clinical Supervision) Acheson and Gall (Pidarta, 1992:249) menyatakan bahwa supervisi klinis adalah proses membina guru untuk memperkecil jurang antara prilaku mengajar nyata dengan perilaku mengajar yang ideal. Sedangkan Lacio (1979:20) memfokuskan kepada upaya untuk menolong guru-guru agar mengerti inovasi dan mengubah performan mereka agar cocok dengan inovasi tersebut. Dengan demikian dapat dikatakan bahwa supervisi klinis adalah suatu model supervisi yang ditujukan untuk memperbaiki KBM dengan melakukan pembinaan-pembinaan sesuai dengan kekurangan-kekurangan yang dilakukan oleh guru. Tujuan supervisi klinis adalah memperbaiki perilaku guru dalam KBM dengan intensif agar peningkatan kualitas pendidikan dapat dicapai. Neagley (1980:198) mensyaratkan suatu kondisi dalam melakukan 
supervisi klinis, yakni (1) menciptakan hubungan baik antara guru dan supervisor, (2) merencanakan aspek perilaku yang akan diperbaiki pada sub bahasan tertentu, (3) merencanakan strategi observasi, (4) mengobservasi guru mengajar, (5) menganalisis KBM oleh guru dan supervisor secara terpisah, (6) merencanakan pertemuan, guru diberi kesempatan menanggapi cara mengajarnya sebelum dibahas secara bersama, dan (7) membuat rencana baru bila aspek perilaku itu belum dapat diperbaiki dan mengulangi dari langkah awal sampai akhir.

\subsection{Model Supervisi Klinis}

Supervisi yang menitik beratkan kepada pelaksanaan kegiatan belajar mengajar kita sebut sebagai supervisi akademik. Untuk melaksanakan supervisi akademik, dapat digunakan sebagai metode misalnya kunjungan kelas, atau pengamatan (observasi) kelas, dan sebagainya.

Supervisi akademik yang akan dibahas disini adalah supervisi yang menggunakan model supervisi klinis. Tujuan supervisi klinis : untuk membantu memodifikasi pola-pola pengajaran yang kurang efektif. Sasaran Supervisi klinis : pengembangan profesional guru dan memotivasi kerja guru. Pada awal tahun delapan puluhan, salah satu pengguna model supervisi klinis ini adalah para instruktur PKG (Pemantapan Kerja Guru) IPA \& Matematika.

Dalam pelatihan $\mathrm{PKG}$, pada waktu kegiatan in Services Training (latihan dalam kerja) para instruktur PKG mengadakan observasi kelas empat peserta PKG mengajar. Sebelum observasi lebih dulu diadakan pertemuan awal (prapengamatan) dengan guru yang bersangkutan, demikian juga sesuai dengan observasi kelas pertemuan balikan (pasca pengamatan). Untuk kegiatan ini instruktur menggunakan instrumen yang berupa :Pedoman wawancara dan pedoman observasi kelas.
Karakteristik Supervisi Klinis, meliputi halhal berikut.

1. Supervisi klinis bertanggung dalam hubungan tata muka antara supervisor dan guru

2. Supervisi klinis bertujuan untuk pengembangan profesional guru

3. Kegiatan supervisi klinis ditekankan kepada aspek-aspek yang menjadi perhatian guru serta observasi kegiatan pengajaran di kelas

4. Observasi dilakukan secara cermat dan mendetail

5. Analisis terhadap observasi dilakukan bersama antara supervisor dan guru

6. Hubungan antara supervisor dan guru harus bersifat kemitraan dan bukan otoriter.

\section{SIMPULAN}

Supervisi/pengawasan merupakan hal yang sangat penting dalam hubugannnya dengan peningkatan mutu pendidikan di sekolah. Dalam melakukan supervisi, seorang supervisor hendaknya memerhatikan hal-hal penting, yaitu (1) Proses Pengawasan/Supervisi, proses pengawasan/supervisi meliputi dua hal, yaitu menetapkan standar-standar pelaksanaan pekerjaan dan pengukuran hasil/pelaksanaan pekerjaan; (2) pengawasan dan konsep sistem, dibahas dua hal pokok, yaitu pegawasan menurut Paham Klasik dan Pengawasan dan Konsep Sistem Cybernetic; (3) Informasi dan pengawasan, dalam hal ini meliputi (a) pengawasan sebagai suatu sistem informasi, (b) jenis-jenis informasi pengawasan, (c) pendekatan sistem dalam pengawasan (feed forward); (4) Pengawasan yang efektif, pengawasan yang efektif didasarkan pada sistem informasi manajemen (MIS) yang efektif. MIS dapat ditetapkan sebagai metode formal untuk memberikan informasi yang dibutuhkan oleh manajer agar dapat melaksanakan tugas secara efektif; (5) Evaluasi program, yaitu pembuatan pertimbangan menurut suatu 
perangkat kriteria yang disepakati dan dapat dipertanggungjawabkan. Salah satu tujuan evaluasi yaitu untuk memperoleh dasar bagi pertimbangan akhir suatu periode kerja, apa yang telah dicapai, apa yang belum dicapai, dan apa yang perlu mendapat perhatian khusus; (6) Prinsip-Prinsip Supervisi/Pengawasan Suasana kemitraan, bersifat praktis, sistematis, objektif, realistis, bersifat bantuan, kreatif, antisipatif, konstruktif, dan kooperatif; (7) sasaran supervisi/pengawasan, sasaran supervisi dapat mengenai kegiatan atau aspek yang disupervisi maupun orang yang melakukannya; (8) model supervisi klinis, supervisi yang menitik beratkan kepada pelaksanaan kegiatan belajar mengajar kita sebut sebagai supervisi akademik. Untuk melaksanakan supervisi akademik, dapat digunakan sebagai metode misalnya kunjungan kelas, atau pengamatan (observasi) kelas, dan sebagainya.

\section{DAFTAR PUSTAKA}

Ace Suryadi. 1990. Mutu Pendidikan Persekolahan dalam Perspektif. Mimbar Pendidikan. IKIP Bandung.

Achmady, Z.A. 1995. Beberapa Agenda Peningkatan Mutu Pendidikan Dasar dan Menengah. Makalah Disajikan pada Temu Ilmiah Nasional Manajemen Pendidikan, IKIP Padang, 1 September 1995.

Amin Widjaya Tunggal, 1993. Manajemen Mutu Terpadu. Jakarta: Rineka Cipta.

Anthony, Robert. N, Glenn A. Welsh, 1995. Fundamentals of Management Accounting. Home Wood Richard D. Irwin.

Ariasa Giri, 2007. Impelentasi Pendidikan Sistem Ganda Bidang Keahlian Teknik Mesin di SMK Negeri 3 Singaraja dalam Perspektif Manajemen. Laporan
Penelitian (Tidak dipublikasikan) IHD Negeri Denpasar.

Boediono, 1995. Peranan Pendidikaqn Dalam Kemajuan Teknologi dan Pembangunan. Makalah Kunci, Konvensi Nasional Agenda Bangsa Pasca 50 Tahun Indonesia Merdeka, Bukit Tinggi 198 Nopember 1995. Brameld, Theodore, 1957. Cultural Foundations Of Education. New York : University Press.

Buchori, Mochtar. 1994. Spektrum Problematika Pendidikan Indonesia. Yogyakarta : Tiara Wacana

Boediono, 1999, Panduan Manajemen Sekolah, Jakarta: Departemen Pendidikan dan Kebudayaan, Direktorat Jendral Pendidikan Dasar dan Menengah, Direktorat Pendidikan Menengah Umum.

Depdiknas. 2001a. Manajemen Peningkatan Mutu Berbasis Sekolah Panduan Monitoring dan Evaluasi. Jakarta: Dirjen Dikdasmen.

Hersey, Paul \& Blanchard, K.H, 1977. Management Organization Behavior, New Jersey: Englewood Cloffs.

Marwan dan Gugup, 1989. Manajemen Lanjutan. Jakarta: Karunika Jakarta, Universitas Terbuka.

Pidarta, Made. 1998. Manajemen Pendidikan Indonesia. Jakarta: Bina Aksara.

Pidarta, Made. 1997.Landasan Kependidikan Stimulus Ilmu Pendidikan Bercorak Indonesia. Jakarta : Rineka Cipta

Stoner, James A.F/Wankel Charles, 1986. Manajemen (Alih Bahasa Wihelmus W. Bakowatun), Jakarta: Intermedia. 